\title{
Methodology of Research Activity Development in Preparing Future Teachers with the Use of Information Resources
}

\author{
Hui Cao ${ }^{{ }^{*}}$, Makhabbat B. Amanbayeva ${ }^{2 *}$, Assiya D. Maimatayeva ${ }^{2}$, Zulfiya O. Unerbayeva ${ }^{2}$, \\ Karatay I. Shalabayev ${ }^{2}$, Sergey V. Sumatokhin ${ }^{3}$, Sofya K. Imankulova ${ }^{2}$, Jumadil B. Childibayev ${ }^{2}$ \\ ${ }^{1}$ Shanghai Jiaotong University, Shanghai, CHINA \\ ${ }^{2}$ Abai Kazakh National Pedagogical University, Almaty, KAZAKHSTAN \\ ${ }^{3}$ Moscow State Pedagogical University, Moscow, RUSSIA
}

Received 11 June 2017 - Revised 28 August 2017 • Accepted 15 September 2017

\begin{abstract}
The modern paradigm of education development has new demands on the professional and personal traits of a teacher, in particular, the ability to organize research activity of schoolchildren and to support their interest in science. The research competence of future teachers is a key characteristic that provides these skills. Properly organized research activity of future science teachers contributes not only to their research competence development, but also to their self-confidence as a professional, and thus, supports their motivation for further improvement in the field of teaching. This article presents a developed model of a methodological system for organizing the research activity development in training the future biologists at the pedagogical university. Based on the model, we have developed a comprehensive program for student's research competence development, which was tested at two courses of a pedagogical university. Comparison of the nine experimental groups (220 students) and nine control groups (218 students) showed that our program designed to develop student's research competence is effective. The paper also discusses the conditions, under which the program is effective, in particular, the importance of continuing education of teacher educators, as well as the necessity of interaction between educational and scientific institutions.
\end{abstract}

Keywords: competence development, research activity, teacher educators, science teaching, biology teachers

\section{INTRODUCTION}

In connection with the growing role of integration processes occurring in the world, demand for quality education has increased significantly (Tondeur et al., 2017). According to UNESCO, ensuring the relevance of higher education to modern requirements is one of the urgent tasks that must be solved by society (UNESCO Science Report: towards 2030, 2015). In the context of globalization, changes in educational systems require the search for new approaches to educational process organization in teacher training institutions, as the goals and content of vocational training significantly change (Whitty, 2014). In particular, both curricula and teaching methods must be revised (Thornton, 2001) in order to provide the quality and relevance of education.

The modern paradigm of education development, in particular lifelong learning and orientation toward the productive combination of science education and educators' education, has new demands on the professional and personal traits of a teacher (Anderson et al., 2011; Labov, Reid, \& Yamamoto, 2010):

\footnotetext{
(C) Authors. Terms and conditions of Creative Commons Attribution 4.0 International (CC BY 4.0) apply.

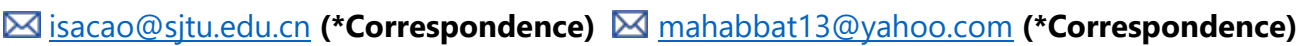




\section{Contribution of this paper to the literature}

- Proposed methodology can increase the efficiency of future biology teacher's professional activity and, accordingly, students' performance.

- The model of the methodological system for organizing the student's research activity development involves the interrelation of target, motivational, content and procedural components.

- The developed model of research activity development and a developed (on its basis) methodology for preparing biology students are effective and can be applied in the framework of the "Invertebrate Zoology" and "Vertebrate Zoology" courses at the pedagogical universities.

- possession of integrative methodology of professional activity;

- ability to analyze and objectively evaluate the proposed educational programs and pedagogical material based on deep knowledge in the field of fundamental natural sciences, to search for the necessary information to solve professional problems;

- ability to create a creative intellectual-search style of one's own professional activity;

- readiness to develop an authorial education program, taking into account the international experience and new learning technologies;

- ability to cooperate and freely communicate in the professional association;

- ability to think critically and creatively;

- ability to continuous self-development, to build up own intellectual potential and professional teaching skills.

At the same time, teaching duties, unlike the scientific research, are evaluated by faculty/staff and are paid lower, and therefore, are rarely considered as a sphere of further improvement (Handelsman et al., 2004). Teachers' preparation for schools, including science teachers, often has much lower scientific standards than the preparation of researchers. Accordingly, graduated teachers do not have sufficient skills in organizing and conducting scientific research and developing recommendation systems on their basis (Adúriz-Bravo et al., 2005). Namely, they do not have a sufficient level of scientific literacy and cannot help students in their research (Eick, 2000). Thus, modern education of science teachers does not allow graduates to be fully professionally trained to teach science.

As in the case of biology students, modern education of future science teachers is characterized by the following contradictions:

- between the increasing demand for future biology teachers, who have mastered the research activity, and the current state of learning the research approaches in higher educational establishments;

- between the opportunities of research activity in training the future biology teachers and the inadequate use of student's abilities and motivation in vocational training;

- between the necessary preparation stage for research competence use in professional activity and the insufficient provision with special methodological means.

Thus, we have to create and implement a comprehensive methodology for biology teacher's research competence development in order to improve the quality their training. This will increase the efficiency of their future professional activity and, accordingly, students' performance. Students, for whom research competence development was one of the primary goals in their training, will be more confident in themselves as specialists because of high qualification that meets modern requirements. They will be more satisfied from professional pedagogical activity if they receive due support of institutions.

The modern education specialist is not only a knowledge transferor, but also a carrier of pedagogical culture (Moore, 2012). Students need to learn not only to reproduce the acquired knowledge and methods of action, but be able to apply them independently in new conditions, to transfer of what they have taken to solve training tasks and practical problems in biology (Abd-El-Khalick, 2006; Carrick, 1983; Prahl, 2017; Fleischner et al., 2017). Research activity is one of them, since it arouses student's need in deepening and updating his/her knowledge (Schallies \& Lembens, 2002). 


\section{METHODOLOGICAL FRAMEWORK}

\section{Research Design}

To develop a comprehensive methodology for research competence development, we have developed a student's (future biology teacher) research activity model first. Based on the model of methodological system for organizing the research activity development, we have developed a program for research competence development in training of future biology teachers.

The program was implemented on the 1st ("Invertebrate Zoology") and the 2nd ("Vertebrate Zoology") courses because the experience in research activity development in training of biology students is being formed gradually.

The first stage (includes the diagnostic stage) involves gradual formation of the procedure content of research activity with the accumulation of knowledge about the territory, on which the student lives, in studying the "Invertebrate Zoology". The purpose of this stage is to identify students, who have developed creative abilities and are prone to research in biology.

The second stage (includes training, research and reflexive stages) involves further deepening, expansion and use of research methods of cognition in studying the content of "Invertebrate Zoology", "Vertebrate Zoology" and elective courses. Such a sequence was chosen because this is how the process of human cognition is built: problembased and discovery learning approaches, requiring less explanations and applied in science education, are effective only if students already have some basic knowledge to understand incoming information and to instruct themselves (Kirschner, Sweller, \& Clark, 2006). At the second stage, students are engaged in training tasks and practical research work included in the curriculum and prepared by teachers, working on individual research topics. The purpose of this stage is to carry out the theoretical preparation of students at a level that allows them to carry out research assignments and to plan their further research independently. This will help them in the future profession through organizing their independent research activity in biology.

We formed two groups of students: the experimental group that included 220 students (aged 18-20) and the control group that included 218 students (aged 18-20), who majored in the same discipline at one university - the Abai Kazakh National Pedagogical University. Initial diagnostics showed that the students have same level of research competence development. Then, participants of the experimental group were engaged in the proposed developed program; students of the control group - in generally accepted one. At the end of the course, final diagnosis of the research competence level was carried out and the groups were compared.

The experimental verification of the hypothesis was conducted using Pearson's chi-squared test. We determined the differences in the levels of formation of the skills under consideration in the participant groups of the experiment. The chi-squared test allows not viewing the analyzed statistical distribution as a function and does not imply preliminary calculation of distribution parameters, which is why its application to serial indicators, which the distinguished levels of formation of research skills are, enables assessing the results of the experimental study with sufficient accuracy.

The $\mathrm{X}^{2}$ criterion was calculated according to formula

$$
T=\frac{1}{N_{1} N_{2}} \sum_{i=1}^{c} \frac{\left(N_{1} O_{2 i}-N_{2} O_{1 i}\right)^{2}}{O_{1 i}+O_{2 i}}
$$

where $N_{1}$ is the number of students in the experimental group;

$N_{2}$ is the number of students in the control group;

$O_{1 i}$ is the number of experimental group students that are on the $i^{\text {th }}$ level of formation of research skills;

$\mathrm{O}_{2 i}$ is the number of control group students that are on the $i^{\text {th }}$ level of formation of research skills;

$c$ is the number of levels, $i$.

The training experiment was preceded by a determination of initial data about the level of formation of research skills in students. The results of the pre-experimental review are presented in Tables 1-4. 
Table 1. Examples of tasks for the development of research activity

\begin{tabular}{|c|c|c|c|}
\hline Task & $\begin{array}{c}\text { Formed } \\
\text { skills }\end{array}$ & $\begin{array}{c}\text { Difficulty } \\
\text { level }\end{array}$ & $\begin{array}{c}\text { Organization } \\
\text { form }\end{array}$ \\
\hline 1 & 2 & 3 & 4 \\
\hline \multicolumn{4}{|l|}{ ANALYTICAL } \\
\hline $\begin{array}{l}\text { Translate these words and word combinations into English in written form. } \\
\text { Половой диморфизм (sexual dimorphism), паразитизм (parasitism), вредители } \\
\text { растений (weeds), беспозвоночные животные (invertebrates), трубки мальпиги } \\
\text { (Malpighian tubules) }\end{array}$ & $\begin{array}{l}\text { analysis - } \\
\text { synthesis }\end{array}$ & I & Individual task \\
\hline $\begin{array}{l}\text { Complete the following collocations with the necessary verbs: } \\
\text { Insects are...; Insects have a...; the insect outer skeleton; The nervous system of an } \\
\text { insect can be divided into a ... and a ... The respiratory system is... }\end{array}$ & $\begin{array}{l}\text { analysis - } \\
\text { synthesis }\end{array}$ & 1 & Individual task \\
\hline \multicolumn{4}{|l|}{ COMPLEX } \\
\hline $\begin{array}{l}\text { Read and translate the sentences, point out their subjects and predicates: } \\
\text { Insects play important roles in biological research. For example, because of its small } \\
\text { size, short generation time and high fecundity, the common fruit fly Drosophila } \\
\text { melanogaster is a model organism for studies in the genetics of higher eukaryotes. } \\
\text { Drosophila melanogaster has been an essential part of studies into principles like } \\
\text { genetics linkage, interactions between genes, chromosomal genetics, development, } \\
\text { behavior and evaluation. }\end{array}$ & $\begin{array}{l}\text { analysis - } \\
\text { synthesis }\end{array}$ & 1 & Individual task \\
\hline
\end{tabular}

Table 2. First-year students' research skill formation at the beginning of the experiment (in \%)

\begin{tabular}{ccccc}
\hline \multirow{2}{*}{ Level of research skills } & \multicolumn{3}{c}{ Indicators of research skill formation by groups } \\
\cline { 2 - 5 } & \multicolumn{2}{c}{ Experimental group } & \multicolumn{2}{c}{ Control group } \\
\cline { 2 - 5 } & Number of students & (\%) & Number of students & (\%) \\
\hline Low & 63 & 59.9 & 63 & 64.2 \\
\hline Average & 42 & 39.9 & 35 & 35.7 \\
\hline High & 0 & 0.0 & 0 & 0.0 \\
\hline
\end{tabular}

Table 3. First-year students' research skill formation at the end of the experiment (in \%)

\begin{tabular}{ccccc}
\hline \multirow{2}{*}{ Table 3. First-year students' research skill formation at the end of the experiment (in \%) } \\
\cline { 2 - 5 } Level of research skills & \multicolumn{4}{c}{ Indicators of research skill formation by groups } \\
\cline { 2 - 5 } & \multicolumn{2}{c}{ Experimental group } & \multicolumn{2}{c}{ Control group } \\
\hline Low & 14 & $\mathbf{N}$ & Number of students & (\%) \\
\hline Average & 63 & 59.9 & 28 & 28.5 \\
\hline High & 28 & 26.7 & 63 & 64.3 \\
\hline
\end{tabular}

Table 4. Second-year students' research skill formation at the beginning of the experiment (in \%)

\begin{tabular}{cccccccc}
\hline \multirow{2}{*}{ Group } & \multirow{2}{*}{$\begin{array}{c}\text { Number of } \\
\text { students }\end{array}$} & \multicolumn{2}{c}{ Low } & \multicolumn{4}{c}{ Level of research skills } \\
\cline { 3 - 8 } & 115 & $\begin{array}{c}\text { Number of } \\
\text { students }\end{array}$ & $\%$ & $\begin{array}{c}\text { Number of } \\
\text { students }\end{array}$ & $\%$ & $\begin{array}{c}\text { Number of } \\
\text { students }\end{array}$ & $\%$ \\
\hline EG & 70 & 60,9 & 45 & 39,1 & 0 & 0,0 \\
\hline CG & 120 & 75 & 62,5 & 40 & 33,3 & 5 & 4,2 \\
\hline
\end{tabular}

\section{Research Competence Development Model}

Research activity development in preparing biology students should be carried out within the framework of all components of the educational process.

The first component is research activity at class. This involves problem-based situations, student's cognitive activity in searching for problem solutions that require knowledge activation, hypotheses generation, experiments, observation, project activities, practical work and research assignments.

The second component is a system of extracurricular work, for example, academic tours and field hands-on training. At the second stage, biology students learn different methods of conducting a research, put experiments, perform reports and learn the objects of nature and industry.

The third component is research activity in student scientific research work. There is no better way to teach science than involving students in carrying out science assignments (Anderson et al., 2011). Therefore, at the third 


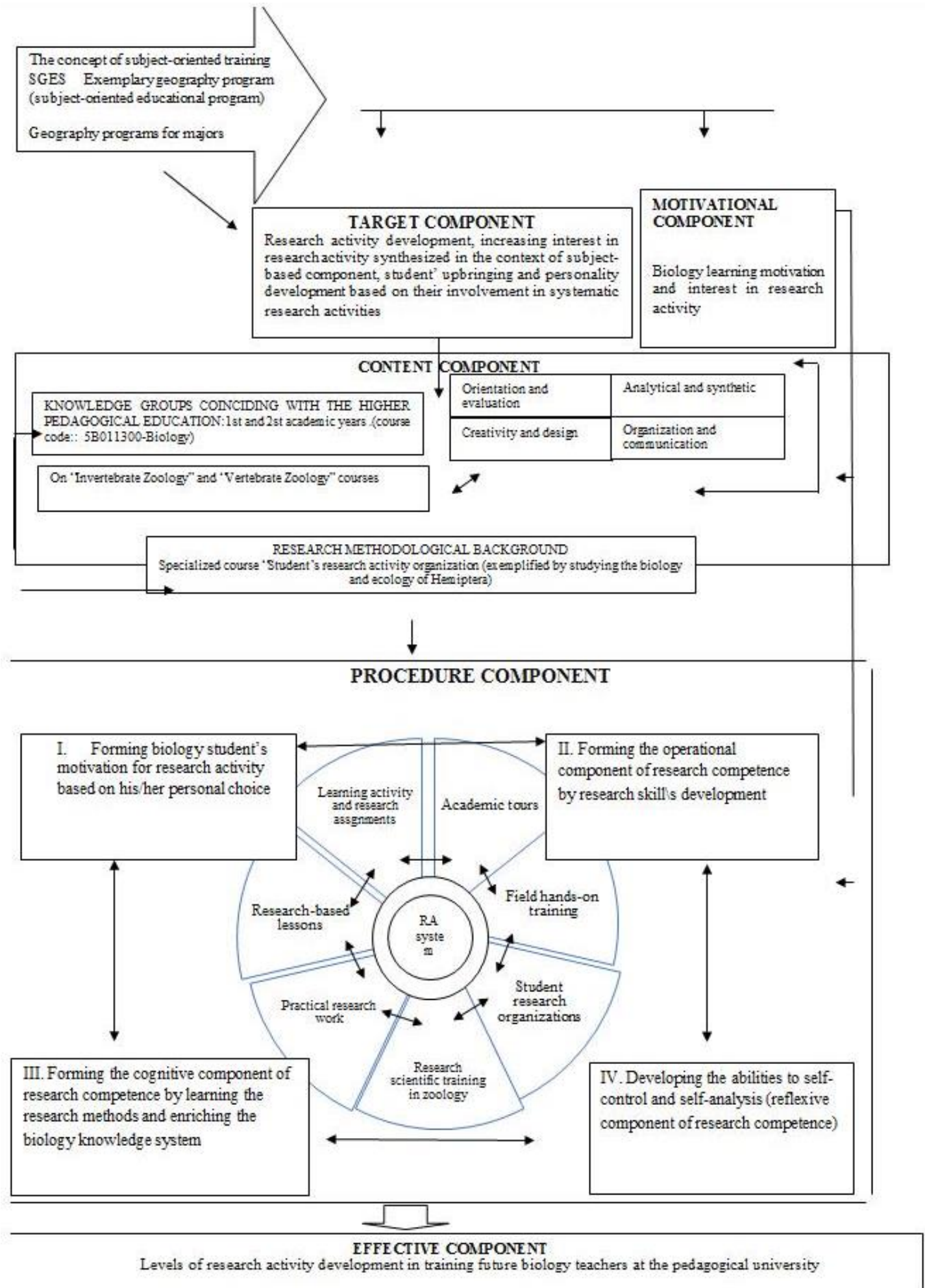

Figure 1. Model of the methodological system for organizing research activity development in training future biology teachers at the pedagogical university

stage, students participate in scientific-practical conferences, research projects of different levels, in various republican and international competitions and programs, as well as prepare the final qualifying paper.

Based on methodological literature, we have developed a model of a methodological system for organizing the research activity development in training biology students (Figure 1). It allows increasing the efficiency of teaching and contributes to research activity development and students' independent work organization. 
Methodological system for organizing the research activity development in training biology students involves a holistic education, based on a special type of interaction between the teacher and students. It promotes the stepby-step formation of research activities, as well as methods, modes and means of teaching that allow organizing result-oriented research activities of different types.

In developing a comprehensive program for student's research competence development, researchers' attention was drawn to the research activities organized within "Invertebrate Zoology", "Vertebrate Zoology" courses for first- and second-year biology students.

The motivational component serves to awaken student's need in forming research skills, to intensify students' activity in mastering these skills and knowledge during the course (Shihusa \& Keraro, 2009). Motivation support and development is achieved by placing the studied phenomenon in a socially and personally meaningful context (Hodson, 2003). Such material presentation allows students to construct personally significant and important knowledge.

In developing a model of a methodological system for research activity development in training future biology teachers, great attention was paid to the regional orientation of the content with taken into account requirements for the regional material use and changes in regional labor markets (Karpuk, 2008). Regional content orientation was achieved by introducing the research into the learning process. At the same time, there was no provision for an increase in the volume of studied theoretical material. This feature is important to consider because the amount of information is one of the factors of informational oversaturation (Chen, Pedersen, \& Murphy, 2012) that leads to a decrease in training efficiency.

The target component of the model is a set of interrelated personality-oriented goals, formulated in accordance with the requirements and trends in modern higher education.

The content component of the model is based on certain parts, including:

- research methodology background, formed within the framework of the specialized course "Student's research activity organization (exemplified by studying the biology and ecology of Hemiptera)";

- research skills and biology knowledge groups, formed in studying the content of "Invertebrate Zoology", "Vertebrate Zoology" courses. This content has wide opportunities for research activity formation and development, which consists of knowledge, research skills, implemented regional (national-regional) component of general education and the ability to use them in practice.

In selecting the content of "Invertebrate Zoology", "Vertebrate Zoology" courses, we made the emphasis on theoretical and practical learning of the biology and ecology of invertebrates (Hemiptera case study) and vertebrates. The content of "Invertebrate Zoology", "Vertebrate Zoology" courses included research problems, which solution requires students to apply different types of methodological and subject research skills. The aim was that the research problems would necessitate the students to develop creative abilities, and thereby, would contribute to creativity formation and development through its basic elements. The creative abilities shown in solving research problems are one of the key qualities of the competencies' informational dimension. They are required by a specialist of the 21st century, since they contribute to knowledge producing (Ananiadou \& Claro, 2009). The second principle of research problem statement is the increasing complexity and compliance with the established criteria of complexity.

Besides the research problems, we have also developed an electronic textbook "Invertebrate Zoology", which we included in the educational process. It was developed in accordance with the content of the standard "Zoology" program. Additional theoretical material is presented in the form of hypertexts. In addition, e-aids are means of feedback and knowledge assessment, as they have interactive tasks with an immediate response assessment. This e-aid has 15 laboratory works, assignments for student's independent work with a teacher, as well as independent tasks, which will allow students to develop research activity and increase their interest in the subject.

In the course of the study, we have developed a system of research assignments for biology students, which provide for different performance duration and a different number of participants. There are different types of assignments in terms of structural-operational solution and levels of complexity:

$$
\begin{aligned}
& 1 \text { - reproductive; } \\
& 2 \text { - partial search; } \\
& 3 \text { - research. }
\end{aligned}
$$

There are six basic types of research assignments applicable to students at the pedagogical university (Trushchenko, 2007). In relation to biology students, they have the following content: 
1. Analytical: definition and classification activities, assignments for systematization of geographical concepts and for determination of biological and ecological features of invertebrates (exemplified by Hemiptera) and vertebrates (exemplified by snakes), watching the living objects of nature; tasks that direct the biology students to work with theoretical biology material.

2. Problem-based: problem-based tasks determined by the gap between the previously acquired knowledge and the new practical conditions for their application; tasks for establishing multi-valued cause-andresearch relationships, requiring an understanding of dialectical contradictions; tasks, based on a scientific hypothesis; tasks-paradoxes; knowledge extraction tasks, which can develop ability to use the only knowledge that can provide the right solution.

3. Stimulating-motivational: tasks that encourage biology students to participate in environmental activities, biological conferences, republican and international competitions and projects, as well as assignments focused on regional material that can awaken interest in biology and form a citizen who wants to take an active part in his/her land development.

4. Project: tasks, which involve the creation and defense of a research project. It can be a model, product, business plan, course work, final qualifying work.

5. Situational: learning activity in a situation as close to life.

6. Comprehensive: tasks combining several different methods of solution, involving the use of several research methods and various forms of presenting results; such tasks, as a rule, involve a multi-stage study of the object or a process.

Consequently, student is necessitated to create own solution scheme, to find a new system of methods. In such activities, hypothesis generation, principle of a problem solution, plan development and solution check are of primary importance. In this case, student's learning outcome is a specific subject performance due to the fact that the goal of science education is not only to provide knowledge, but also to develop analytical skills, to offer an understanding of the research process, to support interest and be accessible to different students (Anderson et al., 2011). In solving research problems, student "discovers" (subjectively) new knowledge about the research object, the method and the means of research activity. Thus, student's personality develops, as well as his/her research skills and abilities.

In solving research tasks, teacher should create the most optimal environment for thinking activity development by constructing hypotheses, discussing and evaluating them, participating in a heuristic conversation, drawing up a plan and experimental procedure to check the most probable research hypotheses. Since the discussion of facts, conclusions and ideas, as well as the exchange of opinions and reasoned discussions about models and concepts, are an integral part of science, these forms of activity must also be present in the educational process of a future scientist (Osborne, 2010). Student's scientific thinking is formed by solvable research problem analysis and study, by clarifying the internal relations and relations between its various elements, by comprehensive objective assessment and by determining the ways of solving a research problem. Thus, special attention should be paid to how biology students generate and check hypotheses (Sampson \& Clark, 2008), namely - how their scientific thinking works.

\section{DATA ANALYSIS}

The purpose of the experimental study is to test the efficiency of developed methodology for research activity development in training future biology teachers at the pedagogical university.

In accordance with the purpose of the experimental study, the following objectives were gradually achieved:

1) studying student's readiness to research;

2) developing and testing the model of a methodological system for organizing research activity development in the training biology students at the pedagogical university;

3) assessing how effective is the developed methodological model.

Accordingly, study was carried out in stages: ascertaining experiment, namely - diagnostics, formative experiment, and, finally, comparison of training programs.

Researcher's non-interference in the educational process organization was a major condition for carrying out the ascertaining experiment. Diagnostic questioning of students of the Abai Kazakh National Pedagogical University was conducted to reveal their level of research skills and to determine the level their readiness to conduct and develop research activities. The questionnaire was drafted according to the following rules: anonymity, openended, closed-ended and indirect questions, as well as basic and rechecking questions.

There are three levels of future teacher's research skills (Romanovskaya, 2010). In relation to students - future biology teachers, they have the following content. 
Low level: students demonstrate a certain interest in research and its results. This interest is unstable: various factors can easily destroy the weak motivation to conduct research. Students are passive in learning. Knowledge about research activity is superficial, unsystematic, not strong enough and used by students at the level of reproduction. Students perform tasks on the model, which they received from the teacher. Students do not know the structure of research activity well; they can perform only certain research activities of the assignment, since they do not understand the logic of the work being done. Students make a significant number of mistakes during the work, which elimination requires teacher's advice and a considerable amount of time.

Average level: students understand the importance of mastering research skills, are sufficiently active in training, but direct not enough efforts on finding the missing knowledge on the theory of research activity. They are not initiative in carrying out research assignments. Students have theoretical knowledge of research activities, but this knowledge is not complete and systematized. At the same time, students understand the necessity and importance of such knowledge. They are able to apply the acquired knowledge in familiar situations independently, but they experience difficulties in applying knowledge in a new situation. The assignment is carried out with teacher's help.

High level: students demonstrate a strong interest in research activities. They realize the importance of research in learning activity, as well as in future professional activity. Students realize it consciously, without the outside help. They demonstrate high activity and initiative in performing research activities. Students have a holistic, solid knowledge about the theory of research activity. They are fully aware of the importance of this knowledge, are able to effectively apply it in a new situation. This level is characterized by student's awareness of what he/she is engaged in. Theoretical knowledge is correctly used to carry out research assignments. Self-contained activity includes all stages of the research assignment, which are performed step-by-step.

Experimental work was carried out during 2013-2015 academic years on the basis of the Abay Kazakh National Pedagogical University. The experimental work was attended by teachers and students of the first and second year, trained in the field of "Biology". In 2013-2014, we have conducted an ascertaining and a trial experiments. In 20142015, we have conducted a formative experiment. In 2015-2016, research results were processed and analyzed.

At the beginning of the study, we have conducted a diagnostic questionnaire with the first- and second-year students, which showed that their training status is at the same level. They were randomly divided into control (CG) and experimental (EG) groups. Then, students of the experimental groups were trained according to the proposed methodology, and the students of the control group - according to the generally accepted one.

In the course of the experiment, we conducted two control sections. The first control section was carried out at the beginning of the experiment, the second - at its end. The results are presented in Tables 2 and 3 . We have checked how the biology student's research activity is formed and developed in training at the pedagogical university.

The study of research activity formation and development among first-year students was conducted in the framework of the "Invertebrate Zoology" course. Since most of the subject-specific theoretical and practical research skills are not formed yet, we have checked those student's research skills they already have at the beginning of the trial experiment. These are theoretical skills of analysis, comparison, systematization, the ability to extract the necessary information, to set the goal of the work, to determine the taxonomy of the Hemiptera order members collected during the excursion.

In comparing the data on research skill formation obtained in these two sections, we have found that the number of students with a high level of research skills increased by $26.7 \%$ in the experimental group and only by $7.1 \%$ in the control group. The number of students, who remained with a low level of research skills, has decreased by $46.6 \%$ in the experimental group and only by $35.7 \%$ in the control group.

Second-year students were developing their research skills in the framework of the "Vertebrate Zoology" course during classroom, laboratory and practical studies, field research. Students were asked to carry out research assignments, they were offered with a result-oriented research work with a possibility to ask the teacher for advice if it necessary. Students have used methods of comparison, analysis and synthesis, observation, generalization, the ability to establish cause-effect relationships. The results of the first and the second control sections on the secondyear student' research skill formation and development are presented in Tables 4 and 5. 
Table 5. Second-year students' research skill formation at the end of the course (in \%)

\begin{tabular}{|c|c|c|c|c|c|c|c|}
\hline \multirow{3}{*}{ Group } & \multirow{3}{*}{$\begin{array}{c}\text { Number of } \\
\text { students }\end{array}$} & \multicolumn{6}{|c|}{ Level of research skills } \\
\hline & & \multicolumn{2}{|l|}{ Low } & \multicolumn{2}{|c|}{ Average } & \multicolumn{2}{|c|}{ High } \\
\hline & & $\begin{array}{c}\text { Number of } \\
\text { students }\end{array}$ & $\%$ & $\begin{array}{l}\text { Number of } \\
\text { students }\end{array}$ & $\%$ & $\begin{array}{c}\text { Number of } \\
\text { students }\end{array}$ & $\%$ \\
\hline EG & 115 & 50 & 43.5 & 45 & 39.1 & 20 & 17.4 \\
\hline CG & 120 & 65 & 54.2 & 45 & 37.5 & 10 & 8.3 \\
\hline
\end{tabular}

In comparing the data on research skill formation obtained in these two sections, we have found that the number of students with a high level of research skills increased by $17.4 \%$ in the experimental group and only by $4,1 \%$ in the control group. The number of students, who remained with a low level of research skills, has decreased by $17.4 \%$ in the experimental group and only by $8.3 \%$ in the control group. Based on the number of students, who switched from a low level of research skills to an average level, number of students with an average level was $39.1 \%$ in the experimental group.

The dynamics of research activity development was traced throughout the experiment. This was necessary to analyze and control the activity of students participating in the experiment, as well as to exclude the possibility of obtaining random results. For example, in carrying out assignments, we found out that such mental operations as analysis and synthesis, as well as determining the cause and effect, we the most difficult activities for students. Students often could not extract the main information, they could not process the data obtained during the work. They found it difficult to generalize the material and to conclude.

\section{DISCUSSIONS}

The developed model of research activity development and a developed (on its basis) methodology for preparing biology students are effective and can be applied in the framework of the "Invertebrate Zoology" and "Vertebrate Zoology" courses at the pedagogical universities. They also can be applied in advanced biology studies.

In evaluating the efficiency of developed methodology, we have used a questioning method, namely - the method of students' self-evaluation. This method has a number of limitations in evaluating competences and cognitive achievements in the field of higher education. In particular, it is not objective enough and does not reflect the complete picture of students' knowledge and skills (Zlatkin-Troitschanskaia, Shavelson, \& Kuhn, 2015). Accordingly, achievement tests that measure the content knowledge in the field of research organization, as well as in the sphere of science research activity and scientific thinking, are one of the areas for the quality improvement of methodology efficiency evaluation. Besides, teachers should set aside some time to interact with students for educational system to be effective. Thus, teachers will obtain feedback about how easy is the material to understand, students will be able to carry out research assignments and conduct self-analysis (Hofstein \& Lunetta, 2004; Subramaniam, 2014). Therefore, in using the methodology, teacher should supplement the efficiency evaluation with observations and in-depth interviews.

Like any other, developed methodology is effective under certain conditions. Teacher's theoretical and methodological readiness, interrelationship of various teaching methods, combination of group and individual methods of research activity organization, as well as the broad applicability of natural objects (in particular, invertebrate and vertebrate species of various taxonomic groups), are the methodological conditions for student's research activity formation.

Research activity is often new to students, despite the fact that many schools have compulsory or additional courses on science methodology and research workshops (Prokop, Tuncer \& Chudá, 2007). For example, student research associations carry out research that is relevant and interesting for schoolchildren if they participate, but in most cases, scientific standards for conducting these studies are not being followed (Vikhoreva, 2009). Therefore, teacher has to trace how the student's research skills form carefully in the first years of study. Successful efficiency evaluation requires emphasizing that students have to understand their projects and the research process, but not that these projects will be presented (Wilson, Howitt, \& Higgins, 2016). Although school research projects contribute to student's understanding of the essence of scientific research and the formation of an ability to organize it, they do not lead to similar progress in understanding the nature of science (Aydeniz, Baksa, \& Skinner, 2011). Therefore, teachers have to pay even more attention to the formation of student's concepts of scientific knowledge and research activity. Teachers should be available to communicate with students on these topics.

It is important to take into account the initial level of research skills, and especially, the initial level of understanding of how the scientific knowledge is produced, as well as the background knowledge in a specific subject area (for example, in biology). This is because there are often problem-based and discovery learning approaches used in modern science education. These approaches, based on the minimal guided instruction, are 
effective in training only if students already have enough knowledge and skills to self-instruct during learning (Kirschner et al., 2006). Accordingly, pedagogical techniques and approaches should be varied depending on the knowledge the students already have.

This feature leads to the next view of the problem, namely - to the importance of skills that possess educators teaching the future teachers. The educator teaching the future teachers inevitably acts as a role model for the latter, even though they often do not recognize or separate the influence of their own teacher behavior on the learning process of student teachers (Lunenberg, Korthagen, \& Swennen, 2007). Therefore, not only the knowledge of teacher educators affect the learning process, but also how they use knowledge in their professional activity, how they organize the learning process and what approaches they use. However, teacher's content knowledge and research skills are also important, since they allow his/her to become critically literate in relation to own pedagogical practice (Hodson, 2003). This helps to improve the quality of teaching. If the educator is able to successfully involve students in research activity, then these future teachers will be more successful in involving schoolchildren in research activity (Hofstein, \& Lunetta, 2004). Therefore, teacher's role as a model for students is particularly noticeable in the field of research-and-development activity.

Finally, the problem of insufficient interaction between such scientific communities as educational researchers and science educators deserves special attention. Although epistemology and pedagogy in a specific field of knowledge are not the same (Kirschner et al., 2006), education of future science teachers requires cooperation of scientific and educational institutions (Anderson et al., 2011; Labov et al., 2010). Teacher's professional development, focused on both the content knowledge and the pedagogical content knowledge, contributes to the development of skills, knowledge and confidence. These qualities are required to create an effective learning environment for students gaining experience in research-and-development activity (Hofstein \& Lunetta, 2004). Academic administration support and feedback, such as prizes, awards and extra vacations for those teachers, who master and develop new pedagogical techniques and apply them in practice (Handelsman et al., 2004), are also important. Thus, continuing period of training and the interaction between educational and scientific institutions contribute to better learning outcomes of science teachers and their further successful professional activity.

\section{CONCLUSION}

The qualitative and actual education of future science teachers involves compulsory training in the field of scientific research. Teacher's research competence is an indispensable condition for their scientific literacy. Therefore, its development in the educational process should be under consideration.

The model of the methodological system for organizing the student's research activity development involves the interrelation of target, motivational, content and procedural components. Thus, it increases the level of student's research skills. Based on the model, we have developed a comprehensive program to develop biology student's research competence. The program was tested with the involvement of the first- and second-year students of a pedagogical university. This contributed to a gradual accumulation of student's research skills. "Vertebrate Zoology" and "Invertebrate Zoology" courses were built in such a way as to promote the analytical thinking development and the acquisition of experience in setting and solving science problems.

On the one hand, incomplete student's understanding of the scientific method and methods of producing scientific knowledge is the most difficult aspect of research competence development. On the other hand, it is the educator's lack of knowledge and skills. Our program of future biology teacher's research competence development contributes to the first- and second-year students' research competence development. At the same time, such program will be effective only if educators have methodological background and high level of professional skills.

\section{REFERENCES}

Abd-El-Khalick, F. (2006). Preservice and experienced biology teachers' global and specific subject matter structures: implications for conceptions of pedagogical content knowledge. Eurasia Journal of Mathematics, Science $\mathcal{E}$ Technology Education, 2(1).

Adúriz-Bravo, A., Bonan, L., Galli, L. G., Chion, A. R., \& Meinardi, E. (2005). Scientific argumentation in pre-service biology teacher education. Eurasia journal of mathematics, science and technology education, 1(1), 76-83.

Ananiadou, K., \& Claro, M. (2009). 21st Century Skills and Competences for New Millennium Learners in OECD Countries (No. 41). http://doi.org/10.1787/218525261154

Anderson, W. A., Banerjee, U., Drennan, C. L., Elgin, S. C. R., Epstein, I. R., Handelsman, J., ... Warner, I. M. (2011). Changing the Culture of Science Education at Research Universities. Science, 331(6014), $152-153$. http://doi.org/10.1126/science.1198280 
Aydeniz, M., Baksa, K., \& Skinner, J. (2011). Understanding the Impact of an Apprenticeship-Based Scientific Research Program on High School Students' Understanding of Scientific Inquiry. Journal of Science Education and Technology, 20(4), 403-421. http://doi.org/10.1007/s10956-010-9261-4

Carrick, T. (1983). Some biology teachers' goals for advanced level teaching. Journal of Biological Education, 17(3), 205-214. http://dx.doi.org/10.1080/00219266.1983.9654543

Chen, C.-Y., Pedersen, S., \& Murphy, K. L. (2012). The influence of perceived information overload on student participation and knowledge construction in computer-mediated communication. Instructional Science, 40, 325-349. http://doi.org/10.1007/s11251-011-9179-0

Eick, C. J. (2000). Inquiry, nature of science, and evolution: the need for a more complex pedagogical content knowledge in science teaching. Electronic Journal of Science Education, 4(3), 1-9.

Fleischner, T. L., Espinoza, R. E., Gerrish, G. A., Greene, H. W., Kimmerer, R. W., Lacey, E. A., ... \& Weisberg, S. (2017). Teaching Biology in the Field: Importance, Challenges, and Solutions. BioScience, 67(6), 558-567. https://doi.org/10.1093/biosci/bix036

Handelsman, J., Ebert-May, D., Beichner, R., Bruns, P., Chang, A., DeHaan, R., ... Wood, W. B. (2004). Scientific Teaching. Science, 304(5670), 521-522. http:// doi.org/10.1126/science.1096022

Hodson, D. (2003). Time for action: Science education for an alternative future. International Journal of Science Education, 25(6), 645-670. http:/ / doi.org/10.1080/09500690305021

Hofstein, A., \& Lunetta, V. N. (2004). The laboratory in science education: Foundations for the twenty-first century. Science Education, 88(1), 28-54. http://doi.org/10.1002/.sce10106

Karpuk, N. V. (2008). Realizing the national-regional component of education in the structure of specialist training. The Journal of Secondary Vocational Education, 1, 42-43.

Kirschner, P. A., Sweller, J., \& Clark, R. E. (2006). Why Minimal Guidance During Instruction Does Not Work: An Analysis of the Failure of Constructivist, Discovery, Problem-Based, Experiential, and Inquiry-Based Teaching. Educational Psychologist, 41(2), 75-86. http://doi.org/10.1207/s15326985ep4102_1

Labov, J. B., Reid, A. H., \& Yamamoto, K. R. (2010). Integrated Biology and Undergraduate Science Education: A New Biology Education for the Twenty-First Century? CBE Life Sciences Education, 9, 10-16. http://doi.org/10.1187/cbe.09-12-0092

Lunenberg, M., Korthagen, F., \& Swennen, A. (2007). The teacher educator as a role model. Teaching and Teacher Education, 23(5), 586-601. http://doi.org/10.1016/j.tate.2006.11.001

Moore, A. (2012). Teaching and learning: Pedagogy, curriculum and culture. Routledge.

Osborne, J. (2010). Arguing to learn in science: The role of collaborative, critical discourse. Science, 328(5977), 463466. http://doi.org/10.1126/science.1183944

Prahl, K. (2017). Best Practices for the Think-Pair-Share Active-Learning Technique. The American Biology Teacher, 79(1), 3-8. http://doi.org/10.1525/abt.2017.79.1.3

Prokop, P., Tuncer, G., \& Chudá, J. (2007). Slovakian Students' Attitudes toward Biology. Eurasia Journal of Mathematics, Science \& Technology Education, 3(4).

Romanovskaya, I. A. (2010). The structure of a future teacher's research attitude. Modern High Technologies, 10, 127131.

Sampson, V., \& Clark, D. B. (2008). Assessment of the ways students generate arguments in science education: Current perspectives and recommendations for future directions. Science Education, 92(3), 447-472. http://doi.org/10.1002/sce.20276

Schallies, M., \& Lembens, A. (2002). Student learning by research. Journal of Biological Education, 37(1), 13-17. http://dx.doi.org/10.1080/00219266.2002.9655840

Shihusa, H., \& Keraro, F. N. (2009). Using Advance Organizers to Enhance Students' Motivation in Learning Biology. Eurasia Journal of Mathematics, Science \& Technology Education, 5(4).

Subramaniam, K. (2014). Student teachers' conceptions of teaching biology. Journal of Biological Education, 48(2), 9197. http://dx.doi.org/10.1080/00219266.2013.837405

Thornton, S. J. (2001). Educating the Educators: Rethinking Subject Matter and Methods. Theory into Practice, 40(1), 72-78. http://doi.org/10.1207/s15430421tip4001_11

Tondeur, J., Pareja Roblin, N., van Braak, J., Voogt, J., \& Prestridge, S. (2017). Preparing beginning teachers for technology integration in education: ready for take-off?. Technology, Pedagogy and Education, 26(2), 157-177. http://dx.doi.org/10.1080/1475939X.2016.1193556 
Trushchenko, Ye. N. (2007). The major areas in organizing the independent work. The Journal of Secondary Vocational Education, 10, 26-28.

UNESCO Science Report: towards 2030. (2015). $\quad$ Retrieved from http:/ / unesdoc.unesco.org/images/0023/002354/235406e.pdf\#235440

Vikhoreva, O. A. (2009). High school students' research activity in further education. The world of science, culture and education, 6, 122-124.

Whitty, G. (2014). Recent developments in teacher training and their consequences for the 'University Project'in education. Oxford Review of Education, 40(4), 466-481. http:/ / dx.doi.org/10.1080/03054985.2014.933007

Wilson, A., Howitt, S., \& Higgins, D. (2016). Assessing the unassessable: making learning visible in undergraduates' experiences of scientific research. Assessment $\mathcal{E}$ Evaluation in Higher Education, 41(6), 901-916. http:/ / doi.org/10.1080/02602938.2015.1050582

Zlatkin-Troitschanskaia, O., Shavelson, R. J., \& Kuhn, C. (2015). The international state of research on measurement of competency in higher education. Studies in Higher Education, 40(3), 393-411. http://doi.org/10.1080/03075079.2015.1004241

\section{http://www.ejmste.com}

